\title{
Paratesticular Soft Tissue Neoplasm
}

National Cancer Institute

\section{Source}

National Cancer Institute. Paratesticular Soft Tissue Neoplasm. NCI Thesaurus. Code C162492.

A mesenchymal neoplasm that arises from the paratesticular region. 